\title{
STUDY OF SOIL-PLANT (POTATO AND BEETROOT)-ANIMAL CYCLE OF NUTRITIVE AND HAZARDOUS MINERALS IN A RABBIT MODEL
}

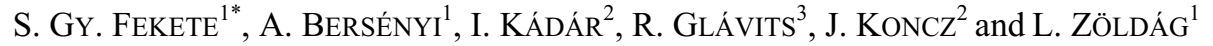 \\ ${ }^{1}$ Department of Animal Breeding, Nutrition and Laboratory Animal Science, Faculty of \\ Veterinary Science, Szent István University, Budapest, H-1400 Budapest, P.O. Box 2, \\ Hungary; ${ }^{2}$ Soil and Agrochemical Research Institute of the Hungarian Academy of Sci- \\ ences, Budapest; ${ }^{3}$ Central Veterinary Institute, Budapest, Hungary
}

(Received December 1, 2000; accepted May 17, 2001)

Potato and beetroot were grown on soils previously treated with heavy metal salts. Each particular microelement had a high concentration in both potato and beetroot [cadmium $(\mathrm{Cd}) 3.7$ and 55.4, lead $(\mathrm{Pb})$ 8.1 and 3.0, and mercury (Hg) 5.8 and $6.8 \mathrm{mg} / \mathrm{kg}$ dry matter, respectively]. In a metabolic balance trial 16 New Zealand White rabbits were fed 50 grams of basal diet and potato or beetroot ad libitum. The apparent digestibility of major nutrients and the accumulation of the microelements in different organs were investigated. Both potato and beetroot samples of high $\mathrm{Pb}$ and $\mathrm{Hg}$ content had the significantly $(\mathrm{p}<0.05)$ lowest digestibility of organic matter and nitrogen-free extract. The $\mathrm{Cd}$ ingested from both potato and beetroot accumulated in the kidneys and liver (2.85 and 1.48 as well as 0.459 and $0.265 \mathrm{mg} / \mathrm{kg}$, respectively). All the microelements $(\mathrm{Cd}, \mathrm{Pb}$ and $\mathrm{Hg}$ ) accumulated in the testicles $(0.196,0.32$ and $0.199 \mathrm{mg} / \mathrm{kg}$, respectively), reducing the rate of spermatogenesis. The tissue retention of heavy metals depends not only on the element itself, but also upon the 'carrier' feedstuff.

Key words: Cadmium, lead, mercury, soil-plant-animal chain, potato, beetroot, rabbit, accumulation

Previous research by the authors has established that the digestibility of nutrients from carrots grown on soils polluted by heavy metal salts is lower for each major nutrient (Fekete et al., 1994; Bersényi et al., 1999). Potatoes and beetroots were also grown on the fields treated with heavy metal salts such as $\mathrm{CdSO}_{4} \cdot 8 \mathrm{H}_{2} \mathrm{O}$, $\mathrm{Pb}\left(\mathrm{NO}_{3}\right)_{2}$ and $\mathrm{HgCl}_{2}$ (Biacs et al., 1995). The purpose of the present study was to determine the digestibility of nutrients in potato tubers and beetroots containing $\mathrm{Cd}, \mathrm{Pb}, \mathrm{Hg}$ at an average concentration of 3.7 and 55.4, 8.1 and 3.0, and 5.8 and $6.8 \mathrm{mg} / \mathrm{kg}$ dry matter, respectively. The retention of the heavy metals was also investigated. Rabbits were used as a model for other farm animals and even for humans.

*Corresponding author; E-mail: safekete@univet.hu; Fax: +36 (1) 478-4128 


\section{Materials and methods}

\section{Experiment 1. Digestibility of nutrients in potato}

All procedures were carried out in the animal facilities of the Department of Animal Breeding, Nutrition and Laboratory Animal Science of the Faculty of Veterinary Science, Budapest.

To determine the apparent digestibility of major nutrients in potato samples, a total of 16 New Zealand White male rabbits (body weight: $2796 \pm 115 \mathrm{~g}$ ) were divided into four groups containing 4 animals each. During a 10-day preliminary (adjustment) period the control group received 50 grams of concentrate (Table 1) and pelleted alfalfa meal ad libitum as basal diet, while the animals in the three experimental treatments were fed a 'feed mixture' containing the basal diet ( $25 \mathrm{~g}$ concentrate, pelleted alfalfa ad libitum) and raw potato ad libitum. This stage was followed by a metabolic balance trial when the daily intake from pelleted alfalfa meal was restricted to $100 \mathrm{~g}$ in the control group or $50 \mathrm{~g}$ in the experimental groups, and potato tubers containing high levels of $\mathrm{Cd}, \mathrm{Pb}, \mathrm{Hg}$, and uncontaminated, 'healthy' ones were offered ad libitum (Table 2). The digestibility of nutrients for each potato sample was calculated by the formula used in a different experiment (Fekete and Gippert, 1982). After the 14-day feeding of potato samples the rabbits were weighed, euthanised painlessly by an overdose of pentobarbital-Na (Nembutal inj. A.U.V., Phylaxia-Sanofi, Budapest), and subjected to pathological examination at the Central Veterinary Instute (Budapest). The heart, liver, lungs, kidneys, spleen, testicles and entire digestive tract were weighed. Appropriate samples taken from the above-mentioned organs as well as from the femoral muscle, jejunum, ileal ampulla (sacculus rotundus) and sternum were fixed in buffered formaldehyde solution. In addition, adipose tissue, bone (femur), hair and urine samples were taken for chemical analysis including determination of the $\mathrm{Cd}, \mathrm{Pb}$ and $\mathrm{Hg}$ content.

The analysis of minerals was performed by using a plasma emission spectrometer (ICP), type JY 24 (JOBEN YVON), in sequential mode at the following wavelengths: $\mathrm{Cd}: 228.802, \mathrm{~Pb}: 220.353$ and $\mathrm{Hg}: 194.227$.

\section{Experiment 2. Digestibility of nutrients in beetroot}

Experiment 2 was conducted in an identical manner as Experiment 1, except that rabbits were fed beetroot samples instead of the potato tubers, ad libitum. The nutrient contents of concentrate and beetroots are shown in Table 3 . The average body weight of rabbits used in Experiment 2 was $2807 \pm 171$ grams. 
Table 1

Ingredients of the pelleted concentrate fed to rabbits

\begin{tabular}{lr}
\hline \multicolumn{1}{c}{ Ingredients } & $\%$ \\
\hline Barley & 38.6 \\
Wheat & 10.0 \\
Maize & 15.0 \\
Wheat bran & 5.7 \\
Extracted sunflower meal (37\% crude protein) & 16.5 \\
Alfalfa meal (22\% crude protein) & 11.7 \\
Lysine & 0.2 \\
Limestone & 1.5 \\
Salt & 0.3 \\
Vitamin-mineral premix & 0.5 \\
\hline Total & 100.0 \\
\hline
\end{tabular}

Table 2

Nutrient content of concentrate, of pelleted alfalfa meal and of potatoes containing heavy metals (\%)

\begin{tabular}{lccrrrr}
\hline \multirow{2}{*}{ Nutrients } & Concentrate & $\begin{array}{c}\text { Pelleted } \\
\text { alfalfa meal }\end{array}$ & \multicolumn{5}{c}{ Potato } \\
\cline { 5 - 7 } & & & $\mathrm{Cd}$ & $\mathrm{Pb}$ & $\mathrm{Hg}$ & uncontaminated \\
\hline \multirow{2}{*}{$\mathrm{DM}$} & 92.18 & 91.76 & 17.96 & 20.50 & 18.83 & 22.85 \\
$\mathrm{Ash}$ & 10.97 & 10.24 & 1.01 & 1.07 & 1.03 & 1.30 \\
$\mathrm{OM}$ & 81.21 & 81.52 & 16.95 & 19.43 & 17.80 & 21.55 \\
$\mathrm{CP}$ & 20.95 & 21.45 & 2.29 & 2.43 & 2.40 & 3.08 \\
$\mathrm{CF}$ & 10.59 & 18.72 & 0.62 & 0.68 & 0.61 & 0.29 \\
$\mathrm{EE}$ & 3.6 & 3.88 & 0.20 & 0.21 & 0.19 & 0.09 \\
$\mathrm{NFE}$ & 46.07 & 37.47 & 13.85 & 16.11 & 14.60 & 18.08 \\
\hline
\end{tabular}

$\mathrm{DM}=$ dry matter; $\mathrm{OM}=$ organic matter; $\mathrm{CP}=$ crude protein; $\mathrm{CF}=$ crude fibre, $\mathrm{EE}=$ ether extract; $\mathrm{NFE}=$ nitrogen-free extract

Table 3

Nutrient content of concentrate and of beetroots containing heavy metals (\%)

\begin{tabular}{lrrrrr}
\hline \multirow{2}{*}{ Nutrients } & Concentrate & \multicolumn{3}{c}{ Beetroot } \\
\cline { 3 - 6 } & & $\mathrm{Cd}$ & $\mathrm{Pb}$ & $\mathrm{Hg}$ & uncontaminated \\
\hline \multirow{2}{*}{$\mathrm{nM}$} & 90.80 & 13.60 & 13.56 & 12.17 & 11.61 \\
$\mathrm{Ash}$ & 7.58 & 1.33 & 1.26 & 1.20 & 0.90 \\
$\mathrm{OM}$ & 83.22 & 12.27 & 12.31 & 10.97 & 10.71 \\
$\mathrm{CP}$ & 15.06 & 2.32 & 2.16 & 2.15 & 1.41 \\
$\mathrm{CF}$ & 15.13 & 0.76 & 0.73 & 0.72 & 0.46 \\
EE & 2.45 & 0.16 & 0.11 & 0.15 & 0.10 \\
$\mathrm{NFE}$ & 50.58 & 9.02 & 9.31 & 7.95 & 8.73 \\
\hline
\end{tabular}

$\mathrm{DM}=$ dry matter; $\mathrm{OM}=$ organic matter; $\mathrm{CP}=$ crude protein; $\mathrm{CF}=$ crude fibre, $\mathrm{EE}=$ ether extract; $\mathrm{NFE}=$ nitrogen-free extract 


\section{Ethical issues, statistical analysis}

The experiment was approved by the Animal Use and Care Administrative Advisory Committee of the Municipal Veterinary Service for Animal Protection and it is in agreement with the Ethical Code of the Hungarian Association for Laboratory Animal Care. Analysis of variance was conducted using the General Linear Models procedure of SPSS ${ }^{\mathrm{TM}}$ software (Norusis, 1988) appropriate for a completely randomised design.

\section{Results}

\section{Experiment 1. Potato}

The nutrient digestibilities of the basal diet and of potato tubers are shown in Table 4 and Fig. 1. Potato ingested ad libitum met only $26 \%$ of the daily dry matter requirement. Data presented in this paper provide evidence that although the digestibility of dry and organic matter of uncontaminated ('healthy') potato differed from that of the basal diet, the difference was not statistically significant. The digestibility of ether extract was significantly improved $(74.92$ vs. $70.55 \%, p<$ 0.05 ) by the addition of potato to the daily ration. The $\mathrm{Pb}$ and $\mathrm{Hg}$ content of potatoes significantly $(\mathrm{p}<0.05)$ decreased the digestibility of organic matter and Nfree extract, but at the same time it improved the digestibility of crude protein and crude fibre. The highest digestibility values of organic matter and $\mathrm{N}$-free extract (66.67 and $72.27 \%$ ), but the worst digestibility of crude protein and crude fibre (71.26 and 36.71\%), were found for potato tubers containing a high level of $\mathrm{Cd}$.

Table 4

Nutrient digestibility of the basal diet and of potato tubers, $\%($ mean $\pm S D ; n=4)$

\begin{tabular}{cccccc}
\hline \multirow{2}{*}{ Nutrients } & Basal diet & \multicolumn{5}{c}{ Potato } \\
\cline { 3 - 6 } & & $\mathrm{Cd}$ & $\mathrm{Pb}$ & $\mathrm{Hg}$ & uncontaminated \\
\hline & & $66.15^{\mathrm{a}}$ & $64.73^{\mathrm{a}}$ & $65.53^{\mathrm{a}}$ & $68.67^{\mathrm{a}}$ \\
$\mathrm{NM}$ & $62.16^{\mathrm{a}}$ & 1.63 & 5.72 & 1.52 & 6.11 \\
$\mathrm{SD}$ & 1.59 & $66.67^{\mathrm{a}}$ & $51.69^{\mathrm{b}}$ & $53.96^{\mathrm{b}}$ & $68.67^{\mathrm{a}}$ \\
$\mathrm{OM}$ & $61.5^{\mathrm{a}}$ & 1.80 & 7.79 & 2.40 & 6.11 \\
$\mathrm{SD}$ & 1.54 & $71.26^{\mathrm{a}}$ & $86.25^{\mathrm{b}}$ & $85.94^{\mathrm{b}}$ & $72.63^{\mathrm{a}}$ \\
$\mathrm{CP}$ & $73.39^{\mathrm{a}}$ & 2.71 & 2.25 & 1.19 & 8.84 \\
$\mathrm{SD}$ & 1.77 & $36.71^{\mathrm{b}}$ & $50.24^{\mathrm{c}}$ & $48.62^{\mathrm{c}}$ & $38.19^{\mathrm{a}}$ \\
$\mathrm{CF}$ & $28.71^{\mathrm{a}}$ & 3.23 & 6.03 & 6.72 & 9.35 \\
$\mathrm{SD}$ & 0.72 & $75.41^{\mathrm{b}}$ & $78.25^{\mathrm{b}}$ & $76.9^{\mathrm{b}}$ & $74.92^{\mathrm{b}}$ \\
$\mathrm{EE}$ & $70.55^{\mathrm{a}}$ & 1.09 & 3.27 & 2.00 & 2.52 \\
$\mathrm{SD}$ & 2.04 & $72.27^{\mathrm{a}}$ & $46.97^{\mathrm{b}}$ & $51.78^{\mathrm{b}}$ & $74.27^{\mathrm{a}}$ \\
$\mathrm{NFE}$ & $67.56^{\mathrm{a}}$ & $4.77^{\mathrm{a}}$ & 10.97 & 3.55 & 5.00 \\
$\mathrm{SD}$ & 2.53 & & & \\
\hline
\end{tabular}

$\mathrm{DM}=$ dry matter; $\mathrm{OM}=$ organic matter; $\mathrm{CP}=$ crude protein; $\mathrm{CF}=$ crude fibre, $\mathrm{EE}=$ ether extract; $\mathrm{NFE}=$ nitrogen-free extract; $\mathrm{a}-\mathrm{b}: \mathrm{p}<0.05 ; \mathrm{a}-\mathrm{c}: \mathrm{p}<0.05 ; \mathrm{b}-\mathrm{c}: \mathrm{p}<0.05$ 


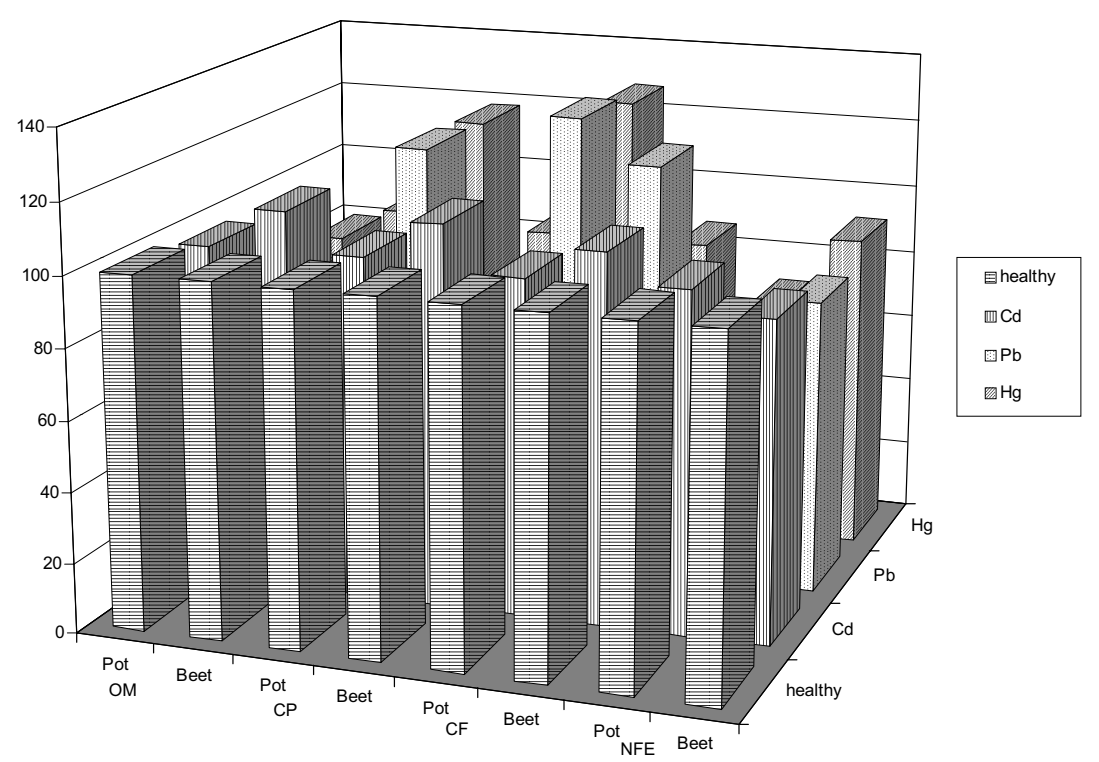

Fig. 1. Apparent digestibility of organic matter (OM), crude protein (CP), crude fibre (CF) and nitrogen-free extract (NFE) in potato (Pot) and beetroot (Beet) samples (in \% of uncontaminated samples)

The body weight measured at the end of the trial (Table 5) was lower in the groups fed with potato samples (between 2.64 and $2.86 \mathrm{~kg}$ ) than that of the group kept on the basal diet $(2.94 \pm 0.52 \mathrm{~kg})$. The average body weight of rabbits in group $\mathrm{Pb}$ was considerably lower than in the group fed uncontaminated potatoes $(2.64 \pm 0.43 \mathrm{~kg}$ vs. $2.86 \pm 0.47 \mathrm{~kg})$.

Table 5

Liveweight of rabbits fed with potato, $\mathrm{kg}($ mean $\pm \mathrm{SD} ; \mathrm{n}=4)$

\begin{tabular}{lccccc}
\hline \multirow{2}{*}{ Liveweight } & Basal diet & \multicolumn{5}{c}{ Potato } \\
\cline { 3 - 6 } & & $\mathrm{Cd}$ & $\mathrm{Pb}$ & $\mathrm{Hg}$ & uncontaminated \\
\hline Initial $\pm \mathrm{SD}$ & $2.90 \pm 0.53$ & $2.73 \pm 0.46$ & $2.60 \pm 0.43$ & $2.87 \pm 0.42$ & $2.88 \pm 0.49$ \\
Final $\pm \mathrm{SD}$ & $2.94 \pm 0.52$ & $2.83 \pm 0.47$ & $2.64 \pm 0.43$ & $2.91 \pm 0.42$ & $2.86 \pm 0.47$ \\
\hline
\end{tabular}

Table 6 shows the amount of microelements retained in the organs and their urinary concentrations. The rate of accumulation of the microelements in the organs was different. Cd accumulated in the kidneys and liver (2.85 and $0.459 \mathrm{mg} / \mathrm{kg}$ dry matter, respectively), $\mathrm{Pb}$ in the spleen, kidneys, bones (femur) and adipose tissue $(2.755,0.608,0.361$ and $0.357 \mathrm{mg} / \mathrm{kg}$, respectively), while $\mathrm{Hg}$ was retained in the kidneys $(8.71 \mathrm{mg} / \mathrm{kg})$. 
Table 6

$\mathrm{Cd}, \mathrm{Pb}$ and $\mathrm{Hg}$ content of the different organs and urine of rabbits fed healthy and contaminated potato, $\mathrm{mg} / \mathrm{kg}$ dry matter $(\mathrm{n}=4)$

\begin{tabular}{lcccccc}
\hline & $\begin{array}{c}\text { Healthy } \\
\mathrm{Cd}\end{array}$ & $\begin{array}{c}\text { Contaminated } \\
\mathrm{Cd}\end{array}$ & $\begin{array}{c}\text { Healthy } \\
\mathrm{Pb}\end{array}$ & $\begin{array}{c}\text { Contaminated } \\
\mathrm{Pb}\end{array}$ & $\begin{array}{c}\text { Healthy } \\
\mathrm{Hg}\end{array}$ & \multicolumn{2}{c}{ Contaminated } \\
$\mathrm{Hg}$
\end{tabular}

Substantial concentrations of $\mathrm{Cd}$ and $\mathrm{Pb}$ were measured in the testicles $(0.196$ and $0.32 \mathrm{mg} / \mathrm{kg}$, respectively). Histological examination revealed that the rate of spermatogenesis in the testicles was reduced in the $\mathrm{Cd}$ - and $\mathrm{Pb}$-affected groups as compared to rabbits fed uncontaminated potatoes. Numerous syncytial giant cells and degenerated cells indicating abnormal meiosis were found among the spermatogenic cells.

According to pathological and histopathological investigation of all rabbits, $\mathrm{Pb}$ loading significantly $(\mathrm{p}<0.05)$ increased the relative weight of the liver, while $\mathrm{Hg}$ loading decreased the relative weight of the kidneys (Table 7).

Table 7

Relative organ weights of rabbits after feeding of potato tubers, $\%$

\begin{tabular}{lcllc}
\hline \multirow{2}{*}{ Organs } & \multicolumn{5}{c}{ Potato } \\
\cline { 2 - 5 } & $\mathrm{Cd}$ & $\mathrm{Pb}$ & $\mathrm{Hg}$ & uncontaminated \\
\hline Heart & 0.19 & 0.22 & 0.18 & 0.22 \\
Liver & 2.59 & $3.01^{\mathrm{a}}$ & 2.26 & $2.49^{\mathrm{b}}$ \\
Lungs & 0.50 & 0.47 & 0.53 & 0.48 \\
Kidneys & 0.51 & 0.58 & 0.49 & 0.59 \\
Testicles & 0.13 & 0.17 & 0.16 & 0.16 \\
Spleen & 0.04 & 0.04 & 0.03 & 0.03 \\
\end{tabular}

a-b: $p<0.05$ 


\section{Experiment 2. Beetroot}

The nutrient digestibilities of the basal diet and of the beetroot samples are shown in Table 8 and Fig. 1. The ad libitum ingested beetroot diet covered approx. $40 \%$ of the daily dry matter requirement. Uncontaminated ('healthy') beetroot had significantly lower digestibility for nutrients than did the concentrate. Beetroot samples of high $\mathrm{Pb}$ and $\mathrm{Hg}$ content had significantly $(\mathrm{p}<0.05)$ lower digestibility of organic matter, crude protein, ether extract and nitrogen-free extract as compared to the concentrate. In case of beetroot samples treated with $\mathrm{Cd}$ or $\mathrm{Pb}$ the digestibility of crude fibre was significantly $(\mathrm{p}<0.05)$ higher.

\section{Table 8}

Digestibility of nutrients in the basal diet and in beetroot, $\%($ mean $\pm S D ; n=4)$

\begin{tabular}{cccccc}
\hline \multirow{2}{*}{ Nutrients } & Concentrate & \multicolumn{5}{c}{ Beetroots } \\
\cline { 3 - 6 } & & $\mathrm{Cd}$ & $\mathrm{Pb}$ & $\mathrm{Hg}$ & uncontaminated \\
\hline $\mathrm{nM}$ & $86.41^{\mathrm{a}}$ & $83.07^{\mathrm{a}}$ & $59.82^{\mathrm{b}}$ & $66.52^{\mathrm{b}}$ & $75.71^{\mathrm{b}}$ \\
$\mathrm{SD}$ & 3.21 & 3.27 & 9.97 & 10.02 & 6.43 \\
$\mathrm{OM}$ & $86.87^{\mathrm{a}}$ & $84.24^{\mathrm{a}}$ & $61.57^{\mathrm{b}}$ & $68.41^{\mathrm{b}}$ & $77.23^{\mathrm{ab}}$ \\
$\mathrm{SD}$ & 3.09 & 2.94 & 9.19 & 9.53 & 6.21 \\
$\mathrm{CP}$ & $86.11^{\mathrm{a}}$ & $82.08^{\mathrm{a}}$ & $56.88^{\mathrm{b}}$ & $64.98^{\mathrm{b}}$ & $75.33^{\mathrm{ab}}$ \\
$\mathrm{SD}$ & 4.15 & 4.05 & 9.68 & 11.17 & 6.81 \\
$\mathrm{CF}$ & $38.08^{\mathrm{a}}$ & $67.93^{\mathrm{b}}$ & $64.68^{\mathrm{b}}$ & $46.81^{\mathrm{a}}$ & $54.32^{\mathrm{ab}}$ \\
$\mathrm{SD}$ & 13.95 & 6.22 & 12.96 & 12.55 & 15.32 \\
$\mathrm{EE}$ & $91.69^{\mathrm{a}}$ & $82.42^{\mathrm{ab}}$ & $64.29^{\mathrm{b}}$ & $69.75^{\mathrm{b}}$ & $78.50^{\mathrm{ab}}$ \\
$\mathrm{SD}$ & 2.62 & 4.15 & 9.31 & 12.35 & 6.67 \\
$\mathrm{NFE}$ & $88.96^{\mathrm{a}}$ & $87.53^{\mathrm{a}}$ & $69.57^{\mathrm{b}}$ & $75.02^{\mathrm{b}}$ & $82.56^{\mathrm{a}}$ \\
$\mathrm{SD}$ & 2.62 & 2.24 & 7.98 & 6.89 & 4.69 \\
\hline
\end{tabular}

$\mathrm{DM}=$ dry matter; $\mathrm{OM}=$ organic matter; $\mathrm{CP}=$ crude protein; $\mathrm{CF}=$ crude fibre, $\mathrm{EE}=$ ether extract; $\mathrm{NFE}=$ nitrogen-free extract; $\mathrm{a}-\mathrm{b}: \mathrm{p}<0.05$

Feeding of beetroot decreased the body weight by $5 \%$ in all experimental groups (Table 9).

Table 9

Liveweight of rabbits fed with beetroot, $\mathrm{kg}($ mean $\pm \mathrm{SD} ; \mathrm{n}=4)$

\begin{tabular}{lccccc}
\hline \multirow{2}{*}{ Liveweight } & Basal diet & \multicolumn{5}{c}{ Beetroot } \\
\cline { 3 - 6 } & & $\mathrm{Cd}$ & $\mathrm{Pb}$ & $\mathrm{Hg}$ & uncontaminated \\
\hline Initial $\pm \mathrm{SD}$ & $2.81 \pm 0.17$ & $2.81 \pm 0.16$ & $2.81 \pm 0.17$ & $2.84 \pm 0.16$ & $2.78 \pm 0.19$ \\
Final $\pm \mathrm{SD}$ & $2.90 \pm 0.15$ & $2.79 \pm 0.10$ & $2.82 \pm 0.14$ & $2.83 \pm 0.08$ & $2.78 \pm 0.07$ \\
\hline
\end{tabular}


Table 10 shows that the rate of accumulation of trace elements differed in the organs examined: Cd accumulated in the kidneys $(1.480 \mathrm{mg} / \mathrm{kg})$ and liver $(0.265 \mathrm{mg} / \mathrm{kg}), \mathrm{Pb}$ in the kidneys $(0.165 \mathrm{mg} / \mathrm{kg})$, lungs $(0.025 \mathrm{mg} / \mathrm{kg})$ and testicles $(0.196 \mathrm{mg} / \mathrm{kg}), \mathrm{Hg}$ in the testicles $(0.199 \mathrm{mg} / \mathrm{kg})$. Histopathological examination revealed that the rate of spermatogenesis was reduced in the $\mathrm{Pb}$ group compared to the control.

\section{Table 10}

$\mathrm{Cd}, \mathrm{Pb}$ and $\mathrm{Hg}$ content of the different organs and urine after feeding of healthy and contaminated beetroot $(\mathrm{mg} / \mathrm{kg}$ dry matter; $\mathrm{n}=4)$

\begin{tabular}{lcccccc}
\hline & Healthy & Contaminated & Healthy & Contaminated & Healthy & \multicolumn{2}{c}{ Contaminated } \\
& $\mathrm{Cd}$ & $\mathrm{Cd}$ & $\mathrm{Pb}$ & $\mathrm{Pb}$ & $\mathrm{Hg}$ & $\mathrm{Hg}$ \\
\hline Heart & 0.008 & 0.217 & 0.019 & 0.000 & 0.000 & 0.000 \\
Lung & 0.031 & 0.017 & 0.000 & 0.025 & 0.000 & 0.000 \\
Liver & 0.366 & 0.265 & 0.000 & 0.000 & 0.000 & 0.000 \\
Kidneys & 0.854 & 1.480 & 0.000 & 0.165 & 0.000 & 0.000 \\
Spleen & 0.01 & 0.032 & 0.189 & 0.000 & 0.000 & 0.000 \\
Testicles & 0.02 & 0.014 & 0.000 & 0.196 & 0.000 & 0.199 \\
Adipose tissue & 0.008 & 0.002 & 0.099 & 0.053 & 0.000 & 0.000 \\
Muscle & 0.035 & 0.018 & 0.011 & 0.000 & 0.000 & 0.000 \\
Bone & 0.012 & 0.008 & 0.000 & 0.000 & 0.000 & 0.000 \\
Hair & 0.015 & 0.011 & 0.112 & 0.000 & 0.000 & 0.000 \\
Urine & 0.021 & 0.026 & 0.023 & 0.031 & 0.000 & 0.000 \\
\hline
\end{tabular}

\section{Discussion}

The smaller body weight of animals fed potato or beetroot samples is probably due to the reduced dry matter intake from the potatoes and beetroots having less than 9.3 MJ DE limits per kg dry matter ingestion (Lebas, 1980; Dehalle, 1981; Maertens, 1995). Since the feed intake capacity of rabbits is a limiting factor, the dilution of digestible energy has common effects on the overall body growth rate as well as on the relative growth of tissues and organs and on body composition (Ouhuyoun, 1998). Moreover, the results of this experiment suggest that the negative effect exerted by high concentrations of certain trace elements studied can hardly, if at all, be monitored by determining the classical biological parameters (feed intake, body weight gain, digestibility coefficients).

The effect of heavy metal content on the digestibility of major nutrients is illustrated in Fig. 1. It seems to be contradictory that whilst the digestibility of organic matter and $\mathrm{N}$-free extract decreases, that of crude protein and fibre improves in case of cadmium-containing samples, but mainly for samples containing lead and mercury. A crude fibre content of $13-16 \%$ with a digestibility of $10-20 \%$ is the optimum in feeds for rabbits (Gippert, 1984). Besides the lower 
content of crude fibre (7-10\%) the digestibility of crude protein may also decrease. In the present study the crude fibre intake was very small (less than 7\%). The lower digestibility of nutrients could be explained either by an impaired enzyme production of the pancreas and/or gut wall (NRC, 1980; Kósa et al., 2000), or by the disadvantageous dietetic effect of low-fibre diet having no 'ballast' character (Colin et al., 1976). The males obtained more crude fibre by the feeding of potatoes contaminated with $\mathrm{Pb}$ and $\mathrm{Hg}$. Due to this the digestibility of crude protein and crude fibre improved. This may be attributed to the influence of metals on the gut microflora (Schneider and Flatt, 1975). The daily crude fibre intake of rabbits fed a commercial diet and pelleted alfalfa meal was slightly higher $(16.01 \%)$ than the optimum level, which might have decreased the digestibility of nutrients.

The accumulation of $\mathrm{Cd}$ and $\mathrm{Pb}$ had a negative effect on spermatogenesis in the breeding males, and the residues present in rabbits for slaughter may pose a risk to the human consumer. Differences in retention after feeding the polluted potato and beetroot demonstrate that the tissue accretion of heavy metals depends not only on the element itself but also upon the 'carrier' feedstuff.

\section{Acknowledgements}

This research was supported by grants from the Hungarian Scientific Research Fund (OTKA T/030359 and T/0266069), and from the Ministry of Culture and Education (FKFP 0644/97). The authors owe thanks to Ms Emese Andrásofszky and Ms Erzsébet Berta for the skilful chemical analysis of samples.

\section{References}

Bersényi, A., Fekete, S., Hullár, I., Kádár, I., Szilágyi, M., Glávits, R., Kulcsár, M., Mézes, M. and Zöldág, L. (1999): Study of soil-plant (carrot)-animal cycle of nutritive and hazardous minerals in a rabbit model. Acta Vet. Hung. 47, 181-190.

Biacs, P. A., Daood, H. G. and Kádár, I. (1995): Effect of Mo, Se, Zn, and Cr treatments on the yield, element concentration, and carotinoid content of carrot. J. Agric. Chem. 43, 589-591.

Colin, M., Maire, C., Vaissaire, J. and Renault, L. (1976): Étude éxperimentale du replacement dans l'aliment pour lapins de la cellulose par des lest minéraleaux: Sable et vermiculite. Rec. Méd. Vét. 152, 457-465.

Dehalle, C. (1981): Équilibre entre les apports azotés et énergétiques dans l'alimentation du lapin en croissance. Ann. Zootec. 30, 171-180.

Fekete, S. and Gippert, T. (1982): Suggestions for the standardization of metabolic experiments with rabbits (in Hungarian). Research Report, Research Institute of Animal Breeding and Nutrition, Herceghalom.

Fekete, S., Hullár, I., Huszenicza, Gy., Kádár, I., Koncz, J., Szilágyi, M., Glávits, R. and Mézes, M. (1994): Digestion, reproductive and metabolic parameters of rabbits fed by $\mathrm{Pb}-, \mathrm{Cd}-$, Hg-, Se- and Mo-containing carrots. In: Pais, I. (ed.) 6th Int. Trace Element Symp., Budapest, July 1994, pp. 197-200. 
Gippert, T. (1984): Effect of fibre of agricultural by-products in meat rabbits' nutrition (in Hungarian). $\mathrm{PhD}$ Thesis, Budapest.

Kósa, E., Fekete, S. and Papp, Z. (2000): Effect of cadmium intake on some digestive enzyme activities in broiler chickens. Enzyme Microbiol. Tech. J. (submitted for publication).

Lebas, F. (1980): Les recherches sur l'alimentation du lapin: évolution au cours des 20 dernières années et perspectives d'avenir. Proc. 2nd World Rabbit Congr., Barcelona, Vol. 2. pp. 76-84.

Maertens, L. (1995): Energy and nutrient requirements of does and their young. Proc. 9th Symposium on Housing and Diseases of Rabbits, Fur-bearing animals and Pet Animals, Celle, pp. 76-91.

Norusis, M. J. (1988): SPSS/PC TM V3.0, Update Manual. SPSS Inc., Chicago, U.S.A.

NRC (1980): Mineral Tolerance of Domestic Animals. National Academy of Sciences, Washington, D. C. Third edition, January 1990.

Ouhuyoun, J. (1998): Influence of the diet on rabbit meat quality. In: De Blas, C. and Wiseman, J. (eds) The Nutrition of the Rabbit. CABI Publishing. Wallingford, Oxon. pp. 177-196.

Schneider, B. H. and Flatt, W. P. (1975): The evaluation of feeds through digestibility experiments. The Univ. Georgia Press, Athens. pp. 233-311. 